\title{
Environmental Conditions Leading to Shellfish Contamination and Related Outbreaks
}

\author{
Haifa Maalouf ${ }^{1}$, Monique Pommepuy ${ }^{1}$ and Françoise S. Le Guyader ${ }^{1,{ }^{*}}$ \\ ${ }^{1}$ IFREMER, Laboratoire de Microbiologie, BP 2110544311 Nantes cedex 03, France \\ *: Corresponding author : F. Le Guyader, email address : sleguyad@ifremer.fr
}

\begin{abstract}
:
Human fecal wastes contain a large variety of viruses that can enter the environment through discharge of waste materials from infected individuals. Despite the high diversity of viruses that are introduced into the environment by human fecal pollution, only a few have been recognized to cause disease in association with consumption of contaminated shellfish. To explain bivalve mollusks contamination, several factors including human epidemiology, virus persistence through sewage treatment plant, and shellfish uptake may be suggested. Considering different outbreaks described in the literature, the most common route for transmission is accidental contamination after heavy rainfall, when extra loads cause an overflow, and release of untreated sewage into the aquatic environment. Outbreak analysis also demonstrates the impact on shellfish consumption of some viral strain transmission and thus their impact on molecular epidemiology, especially for norovirus. To limit shellfish contamination and thus to protect the consumer, the most desirable and effective option is to reduce the viral input.
\end{abstract}

Keywords: Shellfish - Outbreaks - Norovirus - Environmental conditions 


\section{Introduction.}

Shellfish were identified as a vector for human enteric pathogen transmission more than 150 years ago. The practice of consuming either raw or undercooked shellfish can lead to transmission of disease, as human pathogens can accumulate in the shellfish, during their filter-feeding activity. Contamination of shellfish-growing waters with human sewage was recognized as a contributing cause of the outbreaks, leading to the development of bacteriologic criteria to assess the impact of sewage on shellfish and shellfish-growing waters. The institution of regulations to specify acceptable levels of bacterial enteric pathogens in shellfish tissues (European regulation 54/2004/EC) or in waters where shellfish are grown (United State Sanitation program) led to the classification of production areas and assisted in lowering the number of bacterial outbreaks. However gastroenteritis or hepatitis outbreaks linked to shellfish consumption still occur as viral contamination is not yet controlled.

\section{Source of pollution for human enteric viruses.}

A large diversity of viruses may enter the environment through the discharge of waste materials from infected individuals. Enteric viruses, originating from human excreta, cause a wide spectrum of illnesses in man including hepatitis, gastroenteritis, meningitis, fever, rash, and conjunctivitis. Viruses most frequently implicated in outbreaks (hepatitis A virus and norovirus) are reviewed in detail in this special issue (Pintó et al., Atmar et al.). Thus, only a brief description of the principal viruses that have been characterized either in outbreaks or in field studies is given below. Most human enteric viruses induce gastroenteritis either in children or all age groups. Rotaviruses are the main etiological agent of viral gastroenteritis in infants and young children (Estes et al. 2007). They are an important cause of mortality in developing countries, while in the developed world they remain an important cause of morbidity and of hospitalization in young children. They are also increasingly recognized as a cause of infectious diarrhea in adults as well (Anderson et al. 2004). Other viruses, such as astrovirus or adenovirus, give mild symptoms, so their prevalence in the population is not well documented. Poliovirus which causes a devastating neurological disease, is a human enterovirus that, despite vaccination campaigns, is still present in some parts of the world. Other enteroviruses species cause a variety of other clinical syndromes, including respiratory infections, haemorrhagic conjunctivitis and myocarditis (Pallansch et al. 2007). Characteristics of these viruses are summarized in Table 1. Ill people shed norovirus at high levels $\left(5 \times 10^{8}\right.$ to $1.6 \times 10^{12}$ RNA copies /g of stool (Atmar et al. 2008). Additionally, post-symptomatic virus shedding may continue for some time after disease, as demonstrated for enterovirus, hepatitis A virus, and norovirus (Atmar, et al., 2008; Costafreda et al., 2006; Pallansch et al. 2007). For example, norovirus shedding in an experimental human infection model lasted a median of 28 days, with a range from 13 to 56 days, and most subjects were no longer symptomatic by day 4 (Atmar et al. 2008). These data suggest that the impact of continued virus 
shedding from ill and post-symptomatic patient on sewage may be very significant. Entericallyis linked to sanitary and living conditions of the population (Pintó \& Saiz, 2007). Concentrations of $3 \times 10^{5}$ to $5 \times 10^{11}$ RNA copies/g of stool have been reported for HAV (Costafreda et al. 2006.). The regular and predictable pattern of seasonal outbreaks dominates the epidemiology of many exclusively human pathogens (Dowell et al. 2001). The seasonal infection may vary between different pathogens, but the timing and characteristics of the annual outbreak of a single pathogen are remarkably consistent from year to year. More general parameters, such as global climate change, may also have an impact on outbreak seasonality and strain transmission (Rohayem 2009) and the overall impact of environment on infectious diseases needs to be considered (Sansonetti 2009). For example a clear peak of norovirus outbreaks occurs during cold weather months on several continents, with lack of UV, cold temperature, frequent run-off being some of the possible explanations of extensive transmission (Mounts et al. 2000). However, noroviruses continue to circulate endemically throughout the year, and although there is the theoretical possibility of zoonotic spread, currently there is no direct evidence of the existence of a reservoir for re-introduction into the human population (Lopman et al. 2008). Gastroenteritis from all causes predominates during colder months of the year but it does not disappear during summer (Dowell et al. 2001; Lopman et al. 2008). It is now evident that some viruses may be detected all year long, either in sporadic cases of illness or in untreated sewage (da Silva et al.2007; Patel et al. 2008).

Human enteric viruses, being very resistant, may persist in outflow water after treatment in sewage treatment plant. Indeed, they have been frequently detected in treated waters and surrounding rivers. Although wastewater is treated for the purposes of removing bacterial and viral pathogens, treatment is not $100 \%$ effective and wastewater effluent may contain enteric viruses that can contaminate the environment. Concentrations of hundred to thousands genomic copies per liter of treated wastewater can be detected, and seasonal variability is similar to that seen for untreated sewage. Several studies reported a higher frequency of genogroup I (GI) norovirus strains in treated effluent compared to genogroup II strains (van der Berg et al. 2005; Myrmel et al. 2006; da Silva et al. 2007; La Rosa et al. 2007). Haramoto et al. (2006)even reported that all treated sewage samples were positive for GI. GI noroviruses are more resistant to inactivation and removal during the sewage treatment process, though the cause is unclear and should be studied in the future. Some hypothesize that differences in capsid proteins or binding properties may be responsible for different treatment efficiencies amongst norovirus types. Furthermore, GI noroviruses are more often implicated in shellfish- and water-related outbreaks than GII, suggesting that GI has a higher resistance to inactivation in the environment (Lopman et al. 2004; Blanton et al. 2006). Overall noroviruses are found in concentrations ranging from undetectable to $10^{6}$ genome copies/1 of treated wastewater (Pusch et al. 2005; van der Berg et al. 2005; da Silva et al. 2007; Iwai et al. 2009). One study reported that sapovirus was found at concentrations of about 0.5 to $1.8 \times 10^{2}$ genomic copies/liter (Haramoto et al. 2008b). Sewage analysis 
showed that noroviruses and sapoviruses may be detected in treated water all year long (da Silva et al.

Information on virus sources and virus levels in treated wastewaters can be used to estimate the quantities of virus discharged into the environment. Limited data are available to calculate "virus based-flow" or "event-flow" discharges into rivers or estuaries. Nevertheless, recent data suggest that, during non-epidemic periods, less than $10^{3}-10^{4}$ genomic copies/liter of norovirus are present in treated wastewaters. During the epidemic period (winter) the concentration is probably 100- to 1000-fold higher. The rate of reduction of virus concentrations through sewage treatment processes rely on the initial raw sewage concentrations and residence time (Le Cann et al. 2004; Myrmel et al. 2006; Katayama et al. 2008). Many types of wastewater treatment technologies exist and thus performance may be different (da Silva et al. 2007). Viral elimination depends on a wide array of factors, including temperature, solar radiation, adsorption, enzymatic destruction, and predation by bacteria and protozoa. Removal mechanisms are complex and difficult to elucidate, especially for non-culturable viruses. For example association of norovirus to particles has important implications as this may protect viruses from inactivation by shielding, or enhance inactivation by photosensitization of adsorbed macromolecules (da Silva et al. 2008). These data imply that viruses are discharged into environmental waters with a seasonal profile and raises questions about the frequency and duration of such peaks and the importance and impact of storm events that result in a bypass of wastewater treatment during high flow epidemic periods. In the absence of precise information, calculations from epidemiological data suggest that $10^{6}$ norovirus fluxes can be expected from a town of 60,000 population-equivalent during winter outbreaks (Pommepuy et al. 2004). Many environmental factors can have an impact on viral distribution, including currents, estuaries, and tides (Pommepuy et al. 2005b).

Norovirus is detected in surface waters less frequently than in wastewaters, probably due to dilution and/or sedimentation mechanisms occurring during transport in rivers. Norovirus has been detected at frequencies ranging from 5.8\% in a Brazilian river to 53\% in Japan (Haramoto et al. 2008a; Miagostovich et al. 2008). Peak norovirus concentrations of up to $10^{4}$ genome copies/liter of surface waters have been reported, suggesting that the risk of infection can vary quantitatively as well as qualitatively (Lodder et al. 2005; Westrell et al. 2006). Other human enteric viruses have also been detected at various concentrations as noted in a recent review (Gerba 2007). For example, hepatitis A virus is endemic in parts of Italy, and viral RNA has been detected at concentrations ranging from 75 to 730 genomes/liter in Venetian canals (Rose et al. 2006).

Despite efforts to reduce the pollution, human activities produce wastes that are discharged into the sea. When entering in the sea, the free- or bound-microorganisms are subjected to dilution and biosedimentation processes. 
When discharged in the marine environment, microorganisms are subjected to different factors (Figure $1)$ :

- Physical dilution dispersion and sedimentation decrease fecal contamination in coastal areas.

- Physio-chemical conditions, specific to marine water (sunlight radiation, salinity, temperature, $\mathrm{pH}$ ) may influence viral degradation.

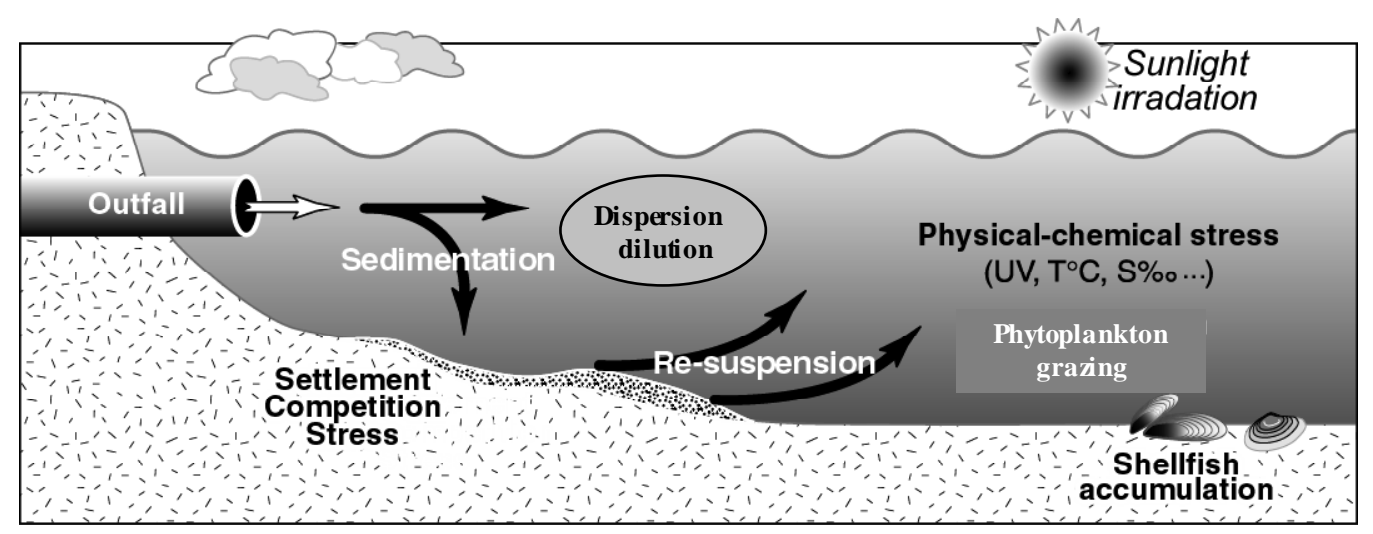

Figure 1: Main factors involved in viral behavior (Pommepuy M. 2005a).

In coastal areas, boats or vessels could also have a significant impact on water and sediment contamination. In a study, fecal load sheds by bathers ranged from $10^{11}$ to $10^{16}$ viruses for 7185 bathers, during the weedend (normal and worst case condition, respectively) (Gerba 2000). The presence of fecal contamination in the environment is the result of flux mixing, accumulation in sediment and shellfish, and microbial persistence. It is important to take the complexity of the coastal environment into account to better understand the behavior of microorganisms in the ocean and the occurrence of pathogens in water, sediment or shellfish. Viral degradation in the sea depends on climatic conditions (e.g. temperature and sunlight exposure). Virus inactivation is considered to proceed as a first-order rate process. The rate of degradation, which encapsulates the effects of a number of different environmental factors, is given by T90, the time for viral concentration to decrease by one log (Schijven et al. 2010). Viruses in marine water are more persistent than Escherichia coli, as demonstrated by T90s values: Escherichia coli (5 h-3.5 d) Poliovirus-1 (10h- 7 d); Hepatitis A virus (3 d-28 d) Astrovirus (16-30 d) (Pommepuy et al. 2005a). Virus attachment to colloid depends on their intrinsic properties (size, electric charge) and then may settle down in the shallow beds of the estuary side. Viruses bind to small size sediment or silts, especially when salinity is low, and they may persist in an infectious state for several months, protected by marine sediments in estuarine waters (Metcalf et al. 1983; Bosch A. 1988; Chung et al. 1993).

\section{Shellfish contamination}


Shellfish pump water over their gills and suspended particles are captured and passed on to the presented to the digestive tract. Food particles enter the stomach through the short esophagus, and particles are sorted further according to size, density and digestibility. The ciliary action of epithelial cells sorts the particles in the stomach as follows: small and heavy (or excess) particles are immediately rejected through the intestinal groove to the midgut while larger or lighter particles are recirculated for further degradation. Food particles are embedded in mucous strings from the esophagus and are carried forward by the rotation of the crystalline style and subjected to mechanical and chemical (mainly glucanases) degradation. Small particles and insoluble molecules enter the digestive gland via the brush-border of the ducts. A second phase of extracellular digestion occurs in the lumen of the tubules, where extracellular enzymes are present. However, intracellular digestion is the main digestive process in this part of the alimentary tract, and then nutrients are transported to the hemolymph, amoebocytes and periglandular connective tissue. Undigested remnants accumulate in residual bodies. In the final phase of the digestive process, the digestive cells break up to release their apical pole filled with residual bodies and lysosomes and are expelled into the lumen of digestive tubules, thereafter reaching the stomach via the ciliated duct section. Waste products are passed on to the rectum via the intestine, where digestion and absorption of some nutrients may also occur (Shumway et al. 1985; Gosling 2003).

It was generally thought that oysters act as mere filters or ionic traps, passively concentrating particles such as bacteria or virus. However, unlike enteric bacterial species, enteric viruses persist in shellfish for an extended period of time. It is this persistence that appears to result in its significant impact on public health. Viruses are principally concentrated in the pancreatic tissue, also called digestive diverticula. A number of different mechanisms have been suggested to explain differences between in virus accumulation between different oyster species, including mechanical entrapment and ionic bonding (Di Girolamo et al. 1977; Metcalf et al. 1982; Schwab et al. 1998; Burkhardt et al. 2000). Virus accumulation in oysters can also depend on factors such as water temperature, mucus production, glycogen content of the connective tissue, and gonadal development. The importance of secreted acid mucopolysaccharides in the concentration of poliovirus was first demonstrated 30 years ago (Di Girolamo et al. 1977). Mucus present on gills was also suspected to be important for concentration of reovirus by oysters (Bedford et al. 1978). Later hepatitis A virus was demonstrated to persist for several weeks after bio-accumulation, with infectious virus being detectable after three weeks and viral RNA still being detectable after six weeks using molecular assays (Kingsley et al. 2003). Infectious adenovirus was still detected in mussels for three weeks following bioaccumulation and in oysters for six weeks (Hernroth et al. 2007).

Virus-like particles (VLPs) have been used to study virus persistence in shellfish. Using rotavirus VLPs in oyster bioaccumulation studies, viral particles persisted in oyster tissues for from one to three months, depending on the input concentrations (Loisy et al. 2005). We used VLPs of the 
prototype genogroup I Norwalk virus (rNV VLP) and native Norwalk virus for bioaccumulation in distribution between the native Norwalk virus and the VLPs, confirming that VLPs are good surrogates of infectious virons for this type of study. Interestingly, virus particle and VLP binding depended on specific cell types, such that some viral particles were detected in phagocytes located either in the epithelium or in the connective tissue (Le Guyader et al. 2006b). This observation might reflect the process of virus elimination or of normal digestion, but it is unclear if the immunoreactive material detected in phagocytes corresponds to particles being degraded and digested or whether particles are able to escape digestion. Specific binding to the main ducts in the digestive tract was observed and may be a mechanism for many viral particles to avoid entering in the food circulation and thus subsequent degradation (Le Guyader et al. 2006b). The existence of a specific attachment to oyster cells and the internalization into phagocytes could explain the difficulty in using depuration to rid oysters of viruses.

Human susceptibility to norovirus infection depends upon the presence or absence of certain carbohydrates of the ABH, secretor and Lewis histo-blood group families (Tan et al. 2007). Using the tissues sections of oyster bodies, we observed that the recognition of oyster digestive epithelial cells by rNV VLPs also involves carbohydrates. Similar to what was observed with human histo-blood group structures, the use of human saliva to inhibit VLP attachment to oyster tissues or the use of mutant VLPs that abolish VLP binding to histo-blood group antigens (alanine subtitution at positions H329A and W375A) prevent binding to oyster tissue. Additional studies showed that the oyster ligands are similar to histo-blood group A. Thus, Norwalk virus binds to oyster tissues through an Alike carbohydrate structure, a binding site also used for attachment to carbohydrate on human epithelial cells (Tan et al. 2007). Norovirus VLPs can also specifically bind to tissues of other oyster species (Crassostrea virginica, Crassostrea sikamea) or clams (Venerupis virginica) or mussels (Mytilis edulis) (Tian et al. 2007). Genetic diversity of NoVs is reflected in their binding capacity to various histo-blood group antigenic structures. Distinct norovirus strains belonging to both genogroup I and II exhibit various binding patterns with different carbohydrate structures of the histo-blood group family, suggesting a possible coevolution of this group of viruses and their host or carrier vector (Le Pendu et al. 2006; Tan et al. 2009). Differences observed between GI.1 and GII.4 binding to human HBGAs are also present in oyster tissues. The distribution of GII.4 is not restricted to digestive tissues as for GI.1 and binds to the different organs using two different ligands (Maalouf et al. submitted). This is in accordance with reports demonstrating the presence of GII.4 in gills, albeit to a lower extent than in digestive tissues (McLeod et al 2009).

\section{Outbreaks descriptions with a focus on the source of the contamination.}

Despite the high diversity of viruses that are introduced into the environment by human fecal pollution, only a few have been recognized to cause disease in association with the consumption of 
contaminated shellfish. Potential explanations for this observation, include a lack of susceptibility of exposure to higher doses than are present in the shellfish to establish infection, and a lack of recognition of disease either through under-reporting or the unavailability of sensitive diagnostic assays. Regulations specify acceptable levels of bacterial enteric pathogens in shellfish tissues or in shellfish growing waters in Europe (European regulation, 91/492/EC) and the United States (National Shellfish Sanitation Program). As depuration failed to eliminate viral contamination (see Richards et al. same issue), some shellfish collected from B area have been implicated in outbreaks (Table 2). However, in many outbreaks, the shellfish and shellfish-growing waters met regulatory criteria for fecal bacterial levels, suggesting an accidental contamination event rather than exposure to a continuous sewage discharge. Frequently the source of accidental events for shellfish contamination cannot be traced (Shieh et al. 2000; Le Guyader et al. 2003.; Prato et al. 2004), but a number of reports have been able to elucidate the cause of human fecal pollution (Table 2). Few outbreaks refer to oyster collected in contaminated area ( $\mathrm{Ng}$ et al. 2005) or people collecting oyster in non-classified area (Sugieda et al. 1996).

The most common route for accidental contamination is sewage overflow and discharge into the aquatic environment during heavy rainfall events. As mentioned above, untreated sewage is likely to be heavily contaminated by enteric viruses. An Australian oyster-associated gastroenteritis outbreak, affecting 2000 persons during the summer in 1978, was the first clear demonstration of this link (Murphy et al. 1979). This outbreak was linked to sewage contamination of the oyster harvesting area near Sydney following heavy rainfall, although not exceptional as similar or greater amounts were recorded several times in the past 25 years. One explanation was possible increased urbanization around the producing area (Murphy et al. 1979). Runoff from heavy spring rains were also suspected to be responsible for 103 clusters of norovirus gastroenteritis involving more than 1000 persons after clam or oyster consumption in New York State in 1982 (Morse et al. 1986). In south of France, heavy rainfall and sewage treatment plant failure were twice implicated as the cause of large gastroenteritis outbreaks due to consumption of oysters harvested from a single lagoon (Le Guyader et al. 2006a; Le Guyader et al. 2008). Before the first outbreak, up to $150 \mathrm{~mm}$ of rainfall occurred in less than one week, resulting in runoff and river overfloow and sewage treatment system failures. Before the second outbreak up to $76 \mathrm{~mm}$ of rain fell in one day, much more than the monthly average of $65.18 \mathrm{~mm}$ shown by data collected over the previous 43 years (Le Guyader et al. 2008). Heavy rain causes the storage capacity of the sewage treatment plant to be exceeded. In combined sewer and rainfall systems, this leads to storm spills. Such discharges result in the release of untreated, heavily contaminated effluent. This may be particularly true during the ,first flush' and this latter outbreak was remarkable by the high diversity of human enteric viruses (up to six different strains) detected both in patient stool and shellfish samples (Le Guyader et al. 2008). 
Considering norovirus shellfish-related outbreaks, strains transmitted are frequently different

The long incubation period of hepatitis A complicates linkage of this agent to particular food exposure incidents, thus few data are available. An outbreak in an Italian school was traced to a family that used to consume clams collected from a contaminated area. Parents and children, two of whom attended the school, were infected and then transmitted the disease to other children, but no information on shellfish contamination was provided (Leoni et al. 1998). In taly, several outbreaks have been linked to illegal storage of shellfish in seawater tanks. There was no further information on the initial source of the contamination (Pontrelli et al. 2008). A sizeable hepatitis A outbreak in the USA in 1973 was linked to Louisiana oysters. The harvesting areas were flooded by the Mississippi River, and there was evidence of sewage contamination based on elevated fecal coliform levels that led to closure of the oyster beds. Subsequently, the oyster beds were reopened to harvesting, but the hepatitis A virus was retained in shellfish for six weeks following the event. At the time of harvesting, oysters were fully compliant with the US sanitation program standard, but were still contaminated with the virus. Unfortunately, no shellfish related to the outbreak could be analyzed (Mackowiak et al. 1976). In 1988 in Shanghai, China, almost 300,000 hepatitis A cases were traced to the consumption of clams harvested from a sewage-polluted area, without any further details on the cause of the contamination (Halliday et al.. 1991). Many other hepatitis A outbreaks linked to bivalve shellfish have been reported but the initiating fecal contamination event has been generally difficult to identify due to the protracted incubation period for this disease (Pintó et al. 2007).

Contamination, due to disposal of faeces from infected individuals from boats, was shown to be the cause of a large gastroenteritis outbreak (Kohn et al. 1995). Epidemiological investigation showed that the outbreak resulted from disposal of human diarrheal stool from a single ill individual directly 
into the waters over the shellfish bed (Kohn et al. 1995). This identification of at least one oyster contamination of several tons of oysters leading to illness among shellfish consumers in five states in the US (Dowell et al. 1995). Considering the high concentration of virus shed in stool and the low infectious dose, such scenario is plausible (Atmar et al. 2008; Teunis et al. 2008). Such contamination was again hypothesized following a hepatitis A outbreak in the US but without any precise documentation, as the long incubation made data collection difficult (Shieh et al. 2007). Regarding outbreak descriptions, illegal actions may play an important role in causing outbreaks, though the initial cause of contamination is often difficult to identify.

One of the first cases implicating illegal activities in a outbreak involved oysters collected in an unapproved area and implicated in hepatitis A cases (Desenclos et al. 1991). A possible fraud with registration documents was suggested in Danemark (Christensen et al. 1998). Recently, in Sweden, oysters collected in a clean area as defined by European regulations, but kept for several days in a guest-harbor (forbidden regarding European regulation 54/2004/EC) were implicated in several cases of gastroenteritis (Nenonen et al. 2009). A hepatitis A outbreak in Italy was caused by mussels that had been kept in sweater tanks for a long time (Lopalco et al. 1997). In France, an outbreak was linked to oysters produced in a clean area, such that no environmental event could explain the multiple contamination of the batch. Later, police arrested a fisherman illegally collecting oysters from a forbidden area, who later admitted to selling them to the producer (Le Guyader et al. 2010). This outbreak illustrates the danger of breaching regulations and refusing to consider the usefulness of the producing area classification.

Other outbreaks reported in the literature referred to shellfish potentially exposed to microbial contamination and sold for cooking. In the US, gastroenteritis cases were reported after the consumption of raw clams in a restaurant. These clams, imported from China packaged and labeled as cooked, had the physical appearance of raw clams and were found contaminated with human enteric virus (Kingsley et al. 2002). In New Zealand, a large gastroenteritis outbreak was linked to oyster consumption, labeled with an advisory to cook the product before consumption. However, these instructions were not followed by the caterer (Simmons et al. 2007). In Australia, frozen imported oysters served grilled were implicated in an outbreak highlighting the resistance of these viruses (Webby et al. 2007). In Spain, two large outbreaks of hepatitis A were linked to the consumption of lightly cooked coquina clam, demonstrating the high resistance of these viruses (Sanchez et al. 2002; Costafreda et al. 2006; Pintó et al., 2009.). Very often, for imported frozen products, it is not possible to identify the area of production from package labeling, emphasizing the need to harmonize regulations.

\section{Conclusion}


Bivalve mollusk (mussels, oysters, clams, etc) production is the only animal aquaculture method that is both environmentally friendly and sustainable. However the filter-feeding nature of bivalves, and, thus, their tendency to concentrate any environmental or man-made contaminant present in their growing waters, requires special attention to food safety issues and compliance with applicable harvesting requirements. On the other hand, seafood is nutritious, tasty, and offers essential components of a healthy diet. Additionally, in some countries, shellfish consumption is an integral part of cultural culinary norms. Thus, it is important to prevent contamination to ensure good quality and consumer safety. This may be performed by a better identification of the source of contamination, understanding processes and mechanisms of virus uptake by mollusk shellfish, and learning about the behavior of viral particles in shellfish tissues.

\section{References}

Anderson, E. J., Weber, S. G. (2004) Rotavirus infection in adults. Lancet infectious disease, 4, 91-99. Atmar, R.L., Opekum, A. R., Gilger, M. A., Estes, M. K., Crawford, S. E., Neill, F. H., Graham, D. Y. (2008) Norwalk virus shedding after experimental human infection. Emerging Infectious Disease, 14, 1553-1557.

Bedford, A.J., Williams, G., Bellamy, A. R.. (1978) Virus accumulation by the rock oyster crassotrea glomerata. Applied Environmental Microbiology, 35, 1012-1018.

Blanton, L.H., Adams, S.M., Beard, R.S., Wei, G., Bulens, S.N., Widdowson, M-A., Glass, R.I., Monroe, S. (2006) Molecular and epidemiologic trends of caliciviruses associated with outbreaks of acute gastroenteritis in the United States, 2000-2004. Journal of Infectious Disease 193, 413-421.

Bosch, A., Lucena, F., Girones, R., Jofre, J. (1988) Occurence of enteroviruses in marine sediment along the coast of Barcelona, Spain. Canadian Journal of Microbiology, 34, 921-924.

Burkhardt, W., Calci, K. R.. (2000) Selective accumulation may account for shellfish-associated viral illness. Applied Environmental Microbiology, 66, 1375-1378.

Chan, M.C.W., Sung, J. J. Y., Lam., R. K. Y., Chan, P. K. S., Lee, N. L. S., Lai, R. W. M., Leung, W. K.. (2006) Fecal viral load and norovirus associated gastroenteritis. Emerging Infectious Disease, 12, 1278-1280.

Christensen, B.F., Lees, D., Henshilwood, K., Bjergskov, T., Green, J. (1998) Human enteric viruses in oysters causing a large outbreak of human food borne infection in 1996/97. Journal of Shellfish Research, 17, 1633-1635.

Chung, H., Sobsey, M. D. (1993) Comparative survival of indicator viruses and enteric viruses in seawater and sediment. Water Science Technology, 27, 425-428.

Costafreda, M.I., Bosch, A., Pintó, R. M.. (2006.) Development, evaluation, and standardization of a real-time taqMan reverse transcription-PCR assay for quantification of hepatitis A virus in clinical and shellfish samples. Applied Environmental Microbiology, 72, 3846- 3855.

da Silva, A., Le Saux, J-C., Parnaudeau, S., Pommepuy, M., Elimelech, M., Le Guyader, F. S.. (2007) Evaluation of removal of noroviruses during wastewater treatment, using real-time reverse transcription-PCR: different behaviors of genogroups I and II. Applied Environmental Microbiology, 73, 7891-7897.

da Silva, A., Le Guyader, F.S., Le Saux, J-C., Pommepuy, M., Montgomery, M.A. Elimelech, M., (2008) Norovirus removal and particle association in a waste stabilisation pond. Environmental Science and Technology, 42, 9151-9157.

Desenclos, J.C.A., Klontz, K. C., Wilder, M. H., Naiman, O. V., Margolis, H. S., Gunn, R.A. (1991) A multistate outbreak of hepatitis A caused by the consumption of raw oysters. American Journal of Public Health, 81, 1268-1272. 
Di Girolamo, R., Liston, J., Matches, J. (1977) Ionic binding, the mechanism of viral uptake by shellfish mucus. Applied Environmental Microbiology,33, 19-25.

Dowell, S. F. (2001) Seasonal variation in host susceptibility and cycles of certain infectious diseases. Emerging and Infectious Disease, 7, 369-374.

Dowell, S.F., Graves, C., Kirkland, K. B., Cicirello, H. G., Ando,T., Jin, Q., Gentsch, J. R., Monroe, S. S., Humphrey, C. D., Slemp, C., Dwyer, D.M., Meriwether, R.A., Glass, R.I. (1995) A multistate outbreak of oyster associated gastroenteritis : implications for interstate tracing of contaminated shellfish. Journal of Infectious Disease, 171, 1497-1503.

Estes M. K., Kapikian, A. Z. (2007) Rotaviruses, in Knipe D. M., Howley P. M. (eds). Fields Virology, Lippincot Williams and Wilkins, Baltimore, MD, 1917-1974.

Gallimore, C., Cheesbrough, J. S., Lamden, K., Bingham, C., Gray, J. (2005) Multiple norovirus genotypes characterised from an oyster-associated outbreak of gastroenteritis. International Journal of Food Microbiology, 103, 323-330.

Gerba, C.P. (2000) Assessment of enteric pathogen shedding by bathers during recreational activity and its impact on water quality. Quantitative Microbiology 2, 55-68.

Gerba, C.P. (2007) Virus occurence and survival in the environmental waters. in: Human Viruses in water. Perspective in Medical Virology, 17, 91-108.

Gosling, E. (2003) How bivalves feed., in: Bivalve Molluscs: biology, ecology and culture, Blackwell Publishing. ISBN 0-85238-234-01, 3987-123.

Halliday, M.L., Kang, L.Y., Zhou, T.R., Hu, M.D., Pan, Q.C., Fu, T.Y., Huang, Y.S., Hu, S.L. (1991) An epidemic of hepatitis A attributable to the ingestion of raw clams in Shangai, china. Journal of Infectious Disease, 164, 852-859.

Haramoto E., Katayama, H., Oguma, K., Ohgaki, S. (2008a) Development of sample storage methods for detecting enteric viruses in environmental water. Journal of Virological Methods, 151, 1-6.

Haramoto, E., Katayama, H., Oguma, K., Yamashita, H., Tajima, A., Nakajima, H., Ohgaki, S. (2006) Seasonal profiles of human noroviruses and indicator bacteria in a wastewater treatment plant in Tokyo, Japan. Water Science and Technology, 54, 301-308.

Haramoto, E., Katayam, H., Phanuwan, C., Ohgaki, S. (2008b) Quantitative detection of sapoviruses in wastewater and river water in Japan. Letters in Applied Microbiology, 46, 408-413.

Hernroth, B., Allard, A. (2007) The persistence of infectious adenovirus (type 35) in mussels (Mytilus edulis) and oysters (ostrea edulis). International Journal of Food Microbiology, 113, 296-302.

Iwai, M., Hasegawa, S., Obara, M., Nakamura, K., Horimoto, E., Takizawa, T., Kurata, T., Sogen, SI., Shiraki, K.. (2009) Continuous presence of noroviruses and sapoviruses in raw sewage reflects infections among inhabitants of Toyoma, Japan (2006 to 2008). Applied Environmental Microbiology, 75, 1264-1270.

Kageyama, T., Shinohara, M., Uchida, K., Fukushi, S., Hoshino, F. B., Kojima, S., Takai, R., Oka, T., Takeda, N., Katayama, K.. (2004) Coexistence of multiple genotypes, including newly identified genotypes, in outbreaks of gastroenteritis due to Norovirus in Japan. Journal of Clinical Microbiology, 42, 2988-2995.

Katayama, H., Haramoto, E., Oguma, K., Yamashita, H., Tajima, A., Nakajima, H., Ohgaki, S. (2008) One-year monthly quantitative survey of noroviruses, enteroviruses and adenoviruses in wastewater collected from six plants in Japan. Water Research, 42, 1441-1448.

Kingsley, D.H., Meade, G. K., Richards, G.P. (2002) Detection of both hepatitis A virus and norwalklike virus in imported clams associated with food-borne illness. Applied Environmental Microbiology, 68, 3914-3918.

Kingsley, D. H., Richards, G. P. (2003) Persistence of hepatitis A virus in oysters. Journal of Food Protection, 66, 331-334.

Kohn, M.A., Farley, T.A., Ando, T., Curtis, M., WIilson, S.A., Monroe, S.S., Baron, R.C., MacFarland, L.M., Glass, R.I. (1995) An outbreak of Norwalk virus gastroenteritis associated with eating raw oysters. Journal of American Medical Association, 273, 466-471.

La Rosa, G., Fontana, S., Di Grazia, A., Iaconelli, M., Pourshaban, M., Muscillo, M. (2007) Molecular identification and genetic analysis of norovirus genogroups I and II in water environments: comparative analysis of different reverse ranscription-PCR assays. Applied Environmental Microbiology, 73, 4152-4161. 
Le Cann, P., Ranarijaona, S., Monpoeho, S., Le Guyader, F. S., Ferré, V. (2004) Quantification of human astroviruses in sewage using real-time RT-PCR. Research in Microbiology, 155, 11-15.

Le Guyader, F. S , Krol, J., Ambert-Balay, K., Ruvoen-Clouet, N., Desaubliaux, B., Parnaudeau, S., Le Saux, J-C., Ponge, A., Pothier, P., Atmar, R. L., Le Pendu, J. (2010) Comprehensive analysis of a norovirus-associated gastroenteritis outbreak, from the environment to the consumer. Journal of Clinical Microbiology,48, 915-920.

Le Guyader, F.S., Bon, F., DeMedici, D., Parnaudeau, S., Bertone, A., Crudeli, S., Doyle, A., Zidane, M., Suffredini, E., Kholi, E., Maddalo, F., Morini, M., Gallay, A., Pommepuy, M., Pothier, P., Ruggeri, F. M. (2006a) Detection of multiple noroviruses associated with an international gastroenteritis outbreak linked to oyster consumption. Journal of Clinical Microbiology, 44, 3878-3882.

Le Guyader, F.S., Neill, F. H., Dubois, E., Bon, F., Loisy, F., Kohli, E., Pommepuy, M., Atmar, R. L.. (2003.) A semi-quantitative approach to estimate Norwalk-like virus contamination of oysters implicated in an outbreak. International Journal of Food Microbiology, 87, 107-112.

Le Guyader, F.S., Loisy, F., Atmar, R. L., Hutson, A. M., Estes, M. K., Ruvoen-Clouet, N., Pommepuy, M., Le Pendu, J. (2006b) Norwalk virus specific binding to oyster digestive tissues. Emerging Infectious Disease, 12, 931-936.

Le Guyader, F.S., Le Saux, J-C., Ambert-Balay, K., Krol, J., Serais, O., Parnaudeau, S., Giraudon, H., Delmas, G., Pommepuy, M., Pothier, P., Atmar, R. L. (2008) Aichi virus, norovirus, astrovirus, enterovirus and rotavirus involved in clinical cases from a French oyster-related gastroenteritis outbreak. Journal of Clinical Microbiology,46, 4011-4017.

Le Pendu, J., Ruvoen-Clouet, N., Kindberg, E., Svensson, L. (2006) Mendelian resistance to human norovirus infections. Seminar in Immunology, 18, 375-386.

Leoni, E., Bevini, C., Espoti, S. D., Graziano, A. (1998) An outbreak of intrafamiliar hepatitis A associated with clam consumption : epidemic transmission to a school community. European Journal of Epidemiology, 14, 187-192.

Lodder, W.J., de Roda-Husman, A. M. (2005) Presence of noroviruses and other enteric viruses in sewage and surface waters in the Netherlands. Applied Environmental Microbiology, 71, 14531461.

Loisy, F., Atmar, R. L., Le Saux, J-C., Cohen, J., Caprais, M-P., Pommepuy, M., Le Guyader, F. S. (2005) Use of Rotavirus virus like particles as surrogates to evaluate virus persistence in shellfish. Applied Environmental Microbiology, 71, 6049-6053.

Lopalco, P. L., Malfait, P., Salmaso, S., Germinario, C., Quarto, M., Barbuti, S. (1997) A persisting outbreak of hepatitis A in Puglia, Italy, 1996: epidemiological follow up. Eurosurveillance, 2, 31-32.

Lopman, B., Zambon, M., Brown, D. W. (2008) The evolution of norovirus, the gastric flu. PlosMedicine 5,e42.

Lopman, B. A., Vennema, H., Kohli, E., Pothier, P., Sanchez, A., Negredo A., Buesa, J., Schreier, E., et al. (2004) Increase in viral gastroenteritis outbreaks in Europe and epidemic spread of new norovirus variant. Lancet, 363, 682-688.

Lysen, M., Thorhagen, M., Brytting, M., Hjertqvist, M., Andersson, Y., Hedlund, K-O. (2009) Genetic diversity among food-borne and waterborne norovirus strains causing outbreak in Sweden. Journal of Clinical Microbiology, 47, 2411-2418.

Maalouf, H., Zakhour, M., Le Pendu, J., Le Saux, J-C., Atmar, R L., Le Guyader, F. S. Norovirus genogroup I and II igands in oysters: tissue distribution and seasonal variations. Applied Environmental Microbiology, submitted.

Mackowiak, P. A., Caraway, T., Portnoy, B. L. (1976) Oyster-associated hepatitis: lessons from the Louisiana experience. American Journal of Epidemiology, 103, 181-191.

McLeod, C., Hay, B., Grant, C., Greening, G., Day, D. (2009) Localization of norovirus and poliovirus in Pacific oysters. Journal of Applied Microbiology, 106, 1220-1230.

Metcalf, T. G. (1982) Viruses in shellfish growing waters. Environmental International, 7, 21-27.

Metcalf, T. G., Melnick, J. L. (1983) Simple apparatus for collecting estuarine sediments and suspended solids to detect solids associated virus. Applied Environmental Microbiology, 45, 323-327. 
Miagostovich, M.P., Ferreira, F. F. M., Guimaraes, F.R., Fumian, T.M., Dniz-Mendes, L., Luz, S. L. B, Silva, L. A., Leite, J. P. G. (2008) Molecular detection and characterization of gastroenteritis viruses occuring naturally in the stream waters of Manaus, central amazonia, Brazil. Applied Environmental Microbiology, 74, 375-382.

Morse, D. L., Guzewich, J. J., Hanrahan, J. P., Stricof, R., Shayegani, M., Deibel, R., Grabau, J. C., Nowak, N. A., Herrmann, J. E., Cukor, G., Blacklow, N. R. (1986) Widespreead outbreaks of clam and oyster associated gastroenteritis. Role of Norwalk virus. New England Journal of Medicine, 314, 678-681.

Mounts, A. W., Ando, T., Koopmans, M., Bresee, J. S., Noel, J., Glass, R. I. (2000) Cold weather seasonality of gastroenteritis associated with Norwalk-like viruses. Journal of Infectious Disease, 181 (suppl), S284-287.

Murphy, A. M., Grohmann, G. S., Christopher, P. J., Lopez, W. A., Davey, G. R., Millsom, R. H. (1979) An australian wide outbreak of gastroenteritis from oysters caused by Norwalk virus. The Medical Journal of Australia, 2, 329-333.

Myrmel, M., Berg, E. M. M., Grinde, B., Rimstad, E. (2006) Enteric viruses in inlet and outlet samples from sewage treatment plants. Journal of Water Health, 04, 197-209.

Nenonen, N.P., Hannoun, C., Olsson, M. B., Bergstrom, T.. (2009) Molecular analysis of an oysterrelated norovirus outbreak. Journal of Clinical Virology, 45, 105-108.

Ng, T. L., Chan, P. P., Phua, T. H., Loh, J. P., Yip, R., Wong, C., Liaw, C.W., Tan, B. H., Chiew, K. T., Chua, S. B., Lim, S., Ooi, P. L., Chew, S. K., Goh, K. T. t al. (2005) Oyster-associated outbreaks of norovirus gastroenteritis in Singapore. Journal of Infection, 51, 413-418.

Noda, M., Fukuda, S., Nishio, O. (2008) Statistical analysis of attack rate in norovirus foodborne outbreaks. International Journal of Food Microbiology, 122, 216-220.

Pallansch, M., Roos, R. (2007) Enteroviruses: polioviruses, coxsackievirus, echoviruses and newer enteroviruses, in Knipe D. M., Howley P. M. (eds). Fields Virology, Lippincot Williams and Wilkins, Baltimore, MD, 839-893

Patel, M.N., Widdowson, M-A., Glass, R.I., Akazawa, K., Vinje, J., Parashar, U. D. (2008) Systematic literature review of role of noroviruses in sporadic gastroenteritis. Emerging Infectious Disease, $14,1224-1231$.

Pinto,R.M., Costafreda,M.I., \& Bosch,A. (2009). Risk Assessment in Shellfish-Borne Outbreaks of Hepatitis A. Applied and Environmental Microbiology 75, 7350-7355.

Pintó, R.M., Saiz, J-C. (2007) Enteric hepatitis Viruses. in: Human Viruses in water. Perspective in Medical Virology, 17, 39-68.

Pommepuy, M., Dumas, F., Caprais, M.P., Camus, P., Le Mennec, C., Parnaudeau, S., Haugarreau, L., Sarrette, B., Vilagines, P., Pothier, P., Kholi, E., Le Guyader, F. S. (2004) Sewage impact on shellfish microbial contamination. Water Science and Technology, 50, 117-124.

Pommepuy, M., Hervio-Heath, D., Caprais, M-P., Gourmelon, M., Le Saux, J-C. Le Guyader, F. S. (2005) Fecal contamination in coastal areas: an engineering approach.in Belkin S., Colwell R. R. (eds). Oceans and Health, Pathogens in the marine environment, Springer,New York, NY, 331-360.

Pontrelli, G., Boccia, D., Di Renzi, M., Massari, M., Giugliano, F., Celentano L. P., Taffon, S., Genovese, D., Di Pasquale, S., Scalise, F., Rapicetta, M., Croci, L., Salmaso, S. (2008) Epidemiological and virological characterization of a large community-wide outbreak of hepatitis A in southern Italy. Epidemiology and Infection, 136, 1027-1034.

Prato, R., Lopalco, P. L., Chironna, M., Barbuti, G., Germinario, C., Quarto, M. (2004) Norovirus gastroenteritis general outbreak associated with raw shellfish consumption in South Italy. BMC Infectious Diseases 4, 1-6.

Pusch, D., Oh, D. Y., Wolf, S., Dumke, R., Schroter-Bobsin, U., Hohne, M., Roske, I., Schreier, E. (2005) Detection of enteric viruses and bacterial indicators in German environmental waters. Archive of virology, 150, 929-947.

Rohayem, J. (2009) Norovirus seasonality and the potential impact of climate change. European Society of Clinical Microbiol and Infectious Diseases, 15, 524-527.

Rose, M.A, Dhar, A. K., Brooks, H. A., Zecchini, F., Gersberg, R. M. (2006) Quantitation of hepatitis A virus and enterovirus levels in the lagoon canals and Lido beach of Venice, Italy, using realtime RT-PCR. Water Research, 40, 2387-2396. 
Sanchez, G., Pintó, R., Vanaclocha, H., Bosch, A. (2002) Molecular characterization of hepatitis A virus isolates from a transcontinental shellfish-borne outbreak. Journal of Clinical Microbiology, 40, 4148-4155.

Sansonetti, P. (2009) Framing a concept and an agenda for infectious diseases in EMBO molecular medicine. EMBO Molecular Medicine 1, 193-194.

Schijven, J.F., Hassanizadeh, S. M., de Roda Husman, A. M. (2010) Vulnerability of unconfined aquifers to virus contamination. Water Research, 44, 1170-1181.

Schwab, K. J., Neill, F.H., Estes, M.K., Metcalf, T.G., Atmar, R.L. (1998) Distribution of Norwalk virus within shellfish following bioaccumulation and subsequent depuration by detection using RT-PCR. Journal of Food Protection, 61, 1674-1680.

Shieh, Y.C., Khudyakov, Y. E., Ganova-Raeva, L. M., Khambaty, F. M., Woods, J.W., Veazey, J. E., Motes, M. L., Glatzer, M. B., Bialek, S. R., Fiore, A. E. (2007) Molecular confirmation of oysters as the vector for hepatitis A in a 2005 multistate outbreak. Journal of Food Protection, $70,145-150$.

Shieh, Y. S. C., Monroe, S. S., Fankhauser, R. L., Langlois, G. W., Burkhardt, W., Baris, R. S. (2000) Detection of Norwalk-like virus in shellfish implicated in illness. Journal of Infectious Disease, 181, 360-366.

Shumway, S.E., Cucci, T. L., Newell, R. C., Yentsch, C. M. (1985) Particles selection, ingestion and absorption in filter feeding bivalves. Journal of Experimental Marine Biology and Ecoogy, 1 91, 77-92.

Siebenga, J. J., Vennema, H., Zheng, D-P., Vinje, J. et al. (2009) Norovirus illness is a global problem: emergence and spread of norovirus GII.4 variants, 2001-2007. Journal of Infectious Disease, 200, 802-812.

Simmons, G., Garbutt, C., Hewitt, J., Greening, G. (2007) A New Zealand outbreak of norovirus gastroenteritis linked to the consumption of imported raw Korean oyters. New Zealand Medical Journal, 120.

Sugieda, M., Nakajima, K., Nakajima, S. (1996) Outbreaks of Norwalk like virus associated gastroenteritis traced to shellfish : coexistence of two genotypes in one specimen. Epidemiology and Infection, 116, 339-346.

Tan, M., Jiang, X. (2007) Norovirus-host interaction: implications for disease control and prevention. Expert Review in Molecular Medicine 9, 1-22.

Tan, M., Xia, M., Chen, Y., Bu, W., Hegde, R. S., Meller, J., Li, X., Jiang, X. (2009) Conservation of carbohydrate binding interfaces-Evidence of human HBGA selection in norovirus evolution. . PlosOne 4, e5058.

Teunis, P. F. M., Moe, C. L., Liu, P., Miller, S. E., Lindesmith, L., Baric, R. S., Le Pendu, J., Calderon, R. L. (2008) Norwalk virus: how infectious is it? Journal of Medical Virology, 80, 1468-1476.

Tian, P., Engelbrektson, A. L., Jiang, X., Zhong, W., Mandrell, R. E.. (2007) Norovirus recognizes histo-blood group antigens on gastrointestinal cells of clams, mussels, and oysters: a possible mechanism of bioaccumulation. Journal of Food Protection, 70, 2140-2147.

van der Berg, H., Lodder, W., van der Poel, W., Vennema, H., de Roda Husman, A-M (2005) Genetic diversity of noroviruses in raw and treated sewage water. Research in Microbiology, 156, 532540 .

Webby, R.J., Carville, K. S., Kirk, M. D., Greening, G., Ratcliff, R. M., Creara, S. K., Dempsey, K., Sarna, M., Stafford, R., Patel, M., Hall, G. (2007) Internationally distributed frozen oyster meat causing multiple outbreaks of norovirus infection n Australia. Clinical and Infectious Disease, 44, 1026-1031.

Westrell, T., Teunis, P., van den Berg, H., Lodder, W., Ketelaars, H., Stenstrom, T. A., de Roda Husman, A-M. (2006) Short- and long-term variations of norovirus concentrations in the Meuse river during a 2-year study period. Water Research, 40, 2613-2620. 
Table 1: Characteristics of the main enteric viruses.

\begin{tabular}{lllllll}
\hline Name & Size & Capside & Genome* & Incubation & Illness & Season \\
\hline Adenovirus & $70 \mathrm{~nm}$ & Complexe & DsDNA- 35,900 bp & $3-10$ days & gastroenteritis & All year \\
Aichi virus & $27-32 \mathrm{~nm}$ & icosahedral & ssRNA- 8,251 bases & $1-2$ days & gastroenteritis & All year \\
Astrovirus & $27-32 \mathrm{~nm}$ & icosahedral & ssRNA- 6,797 bases & $3-5$ days & gastroenteritis & Winter \\
Calicivirus & $27-32 \mathrm{~nm}$ & icosahedral & ssRNA- 7,642 bases & $2-3$ days & gastroenteritis & Winter \\
Enterovirus & $20-30 \mathrm{~nm}$ & icosahedral & ssRNA- 7,200 bases & $7-30$ days & diverse & Summer \\
Rotavirus & $70 \mathrm{~nm}$ & Triple layer & dsRNA, 11 genes & 3 days & gastroenteritis & Winter \\
& & icosahedral & (667 to 3,302 bp) & & & \\
Hepatitis A virus & $27-32 \mathrm{~nm}$ & icosahedral & ssRNA- 7,478 bases & Up to 6 weeks & hepatitis & All year \\
\hline
\end{tabular}

* ds: double strand, bp; base pairs, ss: single strand 
Table 2: Contamination events identified from different outbreaks linked to shellfish consumption worldwide.

\begin{tabular}{|c|c|c|c|c|c|c|c|}
\hline Shellfish & Country & Category & \# cases & Stool analysis & Shellfish analysis & Contamination events & reference \\
\hline Oysters & Japan & - & - & NoV GI & NoV GI, GII & direct sampling on on a rocky beach & Sugieda et al., 1996 \\
\hline Oysters & Danemark & A & 356 & NoV, EV & NoV, EV & $\begin{array}{l}\text { imported product, possible fraud with } \\
\text { registration documents }\end{array}$ & Christensen et al., 1998 \\
\hline Oysters & France & A & 14 & NoV GI & NoV GI, & $\begin{array}{l}\text { No environmental explanation (low E.coli } \\
\text { counts) }\end{array}$ & Le Guyader et al., 2003 \\
\hline Oysters & US (CA) & $A \& B$ & 171 & NoV & NoV & No environmental explanation & Shieh et al., 2000 \\
\hline Oysters & US (LA) & A & 132 & NoV GI, GII & NoV GI & overboard sewage disposal & Kohn et al., 1995 \\
\hline Oysters & Singapore & B & 305 & NoV GII & NoV GII & potential contaminated area & $\mathrm{Ng}$, et al., 2004 \\
\hline Oysters & $\begin{array}{l}\text { France } \\
\text { Italy }\end{array}$ & $\mathrm{B}^{\circ}$ & $\begin{array}{l}127 \\
202\end{array}$ & $\begin{array}{l}\text { NoV GI.4,GII.4, b } \\
\text { NoV GI.6, } 4 \text { GII.4, } 8\end{array}$ & NoV GI.4, GII.4, 8 & $\begin{array}{l}\text { flooding and sewage treatment plant } \\
\text { failure }\end{array}$ & Le Guyader et al., 2006b \\
\hline Oysters & Australia & - & 83 & $\begin{array}{l}\text { NoV GI.4, } 2 \text {, } \\
\text { GII.6,7,9,5,12 }\end{array}$ & NoVGII.4 & imported from Japan & Webby et al. 2007 \\
\hline Oysters & $\begin{array}{l}\text { New } \\
\text { zealand }\end{array}$ & $\mathrm{C}$ & 115 & NoV GI, GII.3, 6,12 & $\begin{array}{l}\text { NoV GI.3, GII.3, } 6,8,7 \text {, } \\
12\end{array}$ & imported frozen for cooking preparation & Simmons et al. 2007 \\
\hline Oysters & Canada & A & 135 & NoV GI.1,2, GII. 3, 4, 5 & NoV GI.2 & widespread contamination & David et al. 2007 \\
\hline Oysters & Sweden & A & 30 & NoV GI.1 & NoV GI.1, GII.3 & $\begin{array}{l}\text { inappropriate storage for } 10 \text { days in corf } \\
\text { sunk in a guest-harbor }\end{array}$ & Nenonen et al. 2009 \\
\hline Oysters & France & A & 205 & $\begin{array}{l}\text { AiV, AV, EV, RV, } \\
\text { NoV GI, GII }\end{array}$ & $\begin{array}{l}\mathrm{AiV}, \mathrm{AV}, \mathrm{RV}, \text { NoV GI, } \\
\text { GII, }\end{array}$ & $\begin{array}{l}\text { flooding and sewage treatment plant } \\
\text { failure }\end{array}$ & Le Guyader et al. 2008 \\
\hline Oysters & France & A & 34 & NoV GII.4, SaV, AiV & NoV GI,II.4 SaV & $\begin{array}{l}\text { Illegal collection of oyster from a } \\
\text { forbidden area }\end{array}$ & Le Guyader et al. 2010 \\
\hline Mussels & Italy & - & 103 & NoV & NoV GII \& GI & No environmental explanation & Prato et al., 2004 \\
\hline clams & US & $\mathrm{B}^{\circ 0}$ & 5 & NoV & NoV GII, + HAV & Frozen imported product & Kingsley et al., 2002 \\
\hline Oysters & US & A & 61 & HAV & HAV & illegal harvest from an unapproved area & Desenclos et al., 1991 \\
\hline Oysters & US & A & 39 & HAV & HAV & $\begin{array}{l}\text { illegal waste dischages from harvest } \\
\text { vessels or reacreational boats, illegal } \\
\text { harvesting in closed areas }\end{array}$ & Sheih et al. 2007 \\
\hline Mussels & Italy & - & 562 & HAV & - & $\begin{array}{l}\text { Probable contaminated area and shellfish } \\
\text { storage in seawater tanks }\end{array}$ & Lopalco et al. 1997 \\
\hline $\begin{array}{l}\text { Mussels, } \\
\text { razor }\end{array}$ & Italy & diverse & 882 & HAV & HAV & $\begin{array}{l}\text { breeding farms from various area and } \\
\text { illegal storage in seawater }\end{array}$ & Pontrelli et al. 2008 \\
\hline
\end{tabular}


Clam

Clam

\section{China}

Spain

A 638*

Spain

184

100

HAV

HAV

HAV

HAV

HAV

HAV

Frozen imported shellfish

Frozen imported shellfish

Halliday et al., 1991

Sanchez et al., 2002

Costafreda et al. 2006.

- : data not specified, $\mathrm{B}^{\circ}$ : depuration specified, $\mathrm{B}^{\circ \circ}$ : based on E.coli counts detected in the sample analyzed, * cases directly linked to clam consumption.

Category (A or B): sanitary classification of the sample based on E.coli detection in shellfish meat (EEC regulation) or in water (US regulation). 